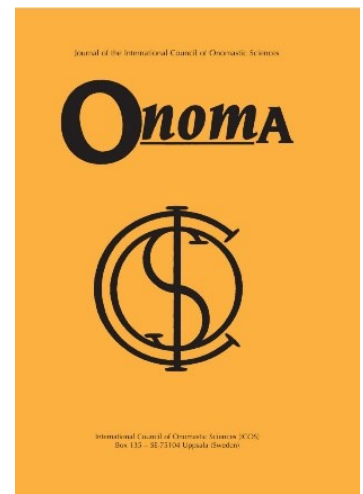

\title{
Onoma 51
}

Journal of the International Council of Onomastic Sciences

ISSN: 0078-463X; e-ISSN: 1783-1644

Journal homepage: https://onomajournal.org/

\section{(Re)naming Hanoi streets after historical people from colonialism to postcolonialism: Creation and recalling collective memories}

DOI: $10.34158 /$ ONOMA.51/2016/3

\author{
Phùng Thị Thanh Lâm \\ VNU-Institute of Vietnamese Studies and Development Sciences \\ Room 103, Building A, \\ 336 Nguyen Trai Street \\ Thanh Xuan District, Hanoi, Vietnam \\ phungthanhlam@gmail.com
}

To cite this article: Phùng Thị Thanh Lâm. 2016. (Re)naming Hanoi streets after historical people from colonialism to postcolonialism: Creation and recalling collective memories. Onoma 51, 25-44. DOI: 10.34158/ONOMA.51/2016/3

To link to this article: https://doi.org/10.34158/ONOMA.51/2016/3

(C) Onoma and the author.

(Re)naming Hanoi streets after historical people from colonialism to postcolonialism: Creation and recalling collective memories

Abstract: Naming streets after historical figures is a political-social trend that has emerged in Vietnam since the French colonial period, and then rapidly became a dominant trend in the process of (re)naming streets. This paper aims to reveal the process of creating and recalling symbols behind (re)naming Hanoi streets between French colonialism and postcolonialism. Based on analysis of archival documents, my paper will point out that (re)naming streets after people is not only the act of executing political power through creating and removing street names but also the 
act of performing traditional values of the nation that can encourage citizens in that nation's war. Also, my paper will determine that Vietnamese political authorities in postcolonialism often inherited the ideologies of commemorating people from former governments. Particularly, names of people who were spiritual symbols in fights against invaders and names of victorious places often are combined to build collective memories which remind residents of the nation's heroic past.

Keywords: Naming streets, colonialism, postcolonialism, commemoration, Hanoi, Vietnam.

\section{Dénomination (changement) des rues de Hanoï basées sur le nom des personnages historiques de la période coloniale à la période postcoloniale : En créant et réveillant des mémoires collectives}

Résumé : Dénomination des noms des rues basées sur le nom des personnages historiques a été la tendance politico-sociale apparue au Vietnam depuis la période coloniale française, puis a été rapidement devenue la tendance dominante dans le processus de dénomination (changement) des rues.

Cette article a pour but de mettre au clair le processus de création de nouveaux symboles et de rappeler les symboles traditionnels de la dénomination (changement) des noms des rues à Hanoï pendant la période coloniale française et la période postcoloniale. En analysant les documents d'archives, notre recherche montrera que la dénomination (changement) des noms des rues selon le nom des hommes célèbres consiste non seulement à renforcer le pouvoir politique en créant et en supprimant les noms des routes, mais aussi à renforcer les valeurs traditionnelles du pays. Cela encourage aussi l'esprit du peuple dans la guerre du pays.

En outre, notre étude précisera également que les institutions politiques vietnamiennes pendant la période postcoloniale héritaient souvent d'idées qui honorent les personnalités historiques des gouvernements précédents. Particulièrement, le nom des personnages qui était un symbole mental dans la guerre contre les envahisseurs et le nom des places faisant des victoires sont souvent combinés pour créer les souvenirs de la communauté, ce qui permet à rappeler au peuple sur un passé héroïque de la nation.

Mots-clés : Noms des rues, coloniale, postcoloniale, commémoration, Hanoï, Vietnam.

\section{Die Um(benennung) der Straßen von Hanoi nach historischen Persönlichkeiten in der Zeit vom Kolonialismus bis zum Postkolonialismus: Schaffung und Wiederbelebung kollektiver Erinnerung}

Zusammenfassung: Die Benennung von Straßen nach historischen Persönlichkeiten begann in Vietnam als ein politischer und gesellschaftlicher Trend in der französischen Kolonialzeit und entwickelte sich schnell zu einem dominanten Trend in der Benennung von Straßen.

Dieser Artikel untersucht den Prozess der Schaffung und Erinnerung von Symbolen im Kontext der Namensgebung von Straßen in Hanoi in der Zeit vom Kolonialismus bis zum Postkolonialismus. Basierend auf Archivarbeiten, zeigt mein Artikel, dass die (Um)benennung von Straßen nach Persönlichkeiten nicht nur ein Akt der Durchsetzung politischer Macht durch das Schaffen neuer und der 
Beseitigung alter Namen ist, sondern auch ein Akt der Darstellung der traditionellen Werte der Nation, die die Bürgerinnen und Bürger dazu bewegen, sich am Krieg zu beteiligen. Darüber hinaus legt mein Artikel dar, dass politische Institutionen im Postkolonialismus häufig die Ideologie des Gedenkens an Personen von vorherigen Regierungen übernehmen. Insbesondere werden Namen von Personen, die spirituelle Symbole im Kampf gegen Eindringlinge waren mit Namen von Orten, an denen ein Sieg errungen wurde, kombiniert, um eine kollektive Erinnerung zu schaffen, die die Bürgerinnen und Bürger an die heroische Vergangenheit des Landes erinnert.

Schlüsselbegriffe: Benennung von Straßen, Kolonialismus, Postkolonialismus, Gedenken, Hanoi, Vietnam. 


\title{
(Re)naming Hanoi streets after historical people from colonialism to postcolonialism: Creation and recalling collective memories
}

\author{
PHÙNG THI THANH LÂM
}

\section{Introduction}

(Re)naming streets after political shifts is a broad political-social issue. As Gill (2005: 482-483) mentioned, in the Soviet Union, (re)naming streets was utilized to "eliminate references to the tsarist period", then, after the fall of the USSR, creating new symbols through Moscow's names "was an early task of new authorities". Similarly, Budapest, where "the process of changing memorial is slower than the process of changing street names", shared this common characteristic (Palonen 2008: 222). Moreover, street names were considered to be a "locus of collective memories" which can display 'community struggles' (Hebbert 2005: 581).

Naming streets blossomed in Hanoi and in other cities of Vietnam following the seizure of power by the French colonial government in Indochina. Before the arrival of the French invaders, Hanoi was described as a city surrounded by some rivers, a city with an ancient citadel, wards of handicrafts and commodities, and roads with stores on both sidewalks. These roads were named by indigenous people after handicrafts and commodities and streets named after people did not exist.

In Vietnam, naming places and geographical features after people used to be a strict taboo before French colonialism. This taboo was shared by China and Korea (Linfu 2014: 94). However, some authors pointed out that this way of naming places had existed in certain areas to express commemoration of people in their names. In Hanoi, for instance, Lý Tế Xuyên, an author of the 14th century, mentioned that Tô Lịch River was named after Lord Tô Lịch. The Lord owned a house near the river, and he was commended by the king because of his benevolence when he lent rice to people in the village in a bad harvest (Lý Tế Xuyên 1960 [reprinted 2012]: 70). Similarly, Tú Uyên lake was named after a Confucian student who met a fairy there (Lê Chất 1818-1821: 494).

In his major study, Ngô Đức Thọ (1997: 37) demonstrated that no evidence involving the taboo of people's name had been promulgated before the Trần Dynasty (1226-1399). According to Ngô Đức Thọ (1997), the taboo 
of the personal names was firstly divided into two categories which were national taboo (name of kings) and royal family taboo (name of queens). In fact, new lists of taboo names were proclaimed by new dynasties reminded people to remember these names (Ngô Đức Thọ 1997: 21). According to these lists, the place names had the sound and the written characters like the names of kings or queens had to be changed. Moreover, family taboo is a moral category in Vietnam that must be popularized to the next generations to avoid naming children after their ancestors (Ngô Đức Thọ 1997: 20). Politely, visitors need to ask the ancestors' names of a family they visit to avoid mentioning these names when talking with house owner.

Between the colonial and postcolonial periods, Hanoi underwent four political authorities comprising French colonial government, Trần Trọng Kim's Cabinet, nine years under the control of the French re-invasion [tam chiếm] (1946-1954), and the Democratic Republic of Vietnam (DRV) which was renamed the Socialist Republic of Vietnam in 1976. To exercise political control over Hanoi city after seizing power, all authorities executed policies that impacted on renaming streets, particularly, renaming with personal names. Like Moscow (Gill 2005: 484), when political shifts happened in Hanoi, personal street names often were renamed by new political authorities while names embedding local identities, such as ancient village names, handicraft names, landmark names, remained.

Although now Hanoi city includes twelve inner districts, one town, and seventeen suburban districts ${ }^{1}$, the contestation of (re)naming streets among political authorities only happened in the area of ancient Hanoi [Hà Nộ $i$ cũ/Hà Nội cổ]. Hence, in this paper, I will examine changing street names in this area which is now mostly four inner districts Ba Đình, Hoàn Kiếm, Đống Đa, and Hai Bà Trưng, an area which was considered as two districts named Vĩnh Thuân and Thọ Xuoong under the Nguyễn Dynasty (see Figure 1). The process of naming Hanoi streets today is continuing with considered questions, however, the questions only involve people who have the right of naming streets and those who have benefits from the act of naming. The political contestation, therefore, is less important than the social-economic contestation.

As time passed, (re)naming streets in Hanoi became a process of accumulating traditional values, in other words, it is a process of filtering the things which fit political authorities' ideologies primarily, then fit the common desire of the people. To explore the political conflicts hidden behind the process of (re)naming Hanoi streets, the time of research will be limited at 1975 because the conflicts among various political authorities had ended

\footnotetext{
http://hanoi.gov.vn/bomaychinhquyen/-/hn/pwxIH8y7LWx0/1605.html (latest access 201805-26).
} 
by this year. In this paper, I will focus on exploring answers for a comparative question that is WHO (Who (was) selected and (was) erased by whom?) and try to answer partly the question WHY (Why he/she was selected and erased?) because "the motivation for the naming process is not often documented and the namer's reasoning for the naming is a matter of speculation" (Tent \& Blair 2011: 69).



Figure 1: Map of four inner districts of Hanoi, namely Ba Đình, Hoàn Kiếm, Đống Đa, and Hai Bà Trưng in the cartography of Vietnam.

\section{Applying street names during French colonialism}

Although naming places after historical figures used to exist in Hanoi, this became a dominant trend of naming streets from the time of French colonialism to commemorate people. Among 129 streets listed by the French municipality in 1890 , there were only fifteen streets named after historical 
figures (Ganter 1895: 258-259). This number increased rapidly, recording 33 streets in 1905 (Gouvernement Général de l'Indo-Chine 1905: 24-30), 128 streets between 1933 and 1934 (Lacroix-Sommé et al. 1933-1934: 505-511), and reaching a peak in 1951 when there were 174 streets named after people (Papeterie 1951). Duplicate naming was commonly utilized by colonial administration.

\subsection{French honorees}

Among fifteen honored people in 1890, the biggest proportion was a group of people who contributed to victories of the French army in the SinoFrench war and in the conquest of Indochina. Boulevard Bobilot, boulevard Carreau, and boulevard Francis Garnier are the examples of this commemoration. A group of both councilors and governors followed, including people who took the part in French Parliament (President Léon Gambetta) and in the Indochina Government (Résident Général Paul Bert, Vice-résident de $1^{\mathrm{e}}$ classe Charles Alexandre Rialan). Two streets were given names after businessmen who owned stores located on these streets: rue Pottier and rue Jean Dupuis. In Le Vieux Tonkin², Claude Bourrin (2007: 90) mentioned that Mr. Pottier, a businessman, had stores on "phố Thợ Thêu" [Embroidery Street]. Especially, Phố Mói [New Street] was given a new name rue Jean Dupuis by Europeans, even at a time he was still alive because this street "là nơi trú ngụ đầu tiên của các thương gia Pháp" [was the initial place where French businessmen inhabited] (Bourrin 2007: 43).

Honoring people who had contributed to the pacification of Indochina was the dominant trend of naming Hanoi streets in early colonialism, however, it seems that the municipal officials did not share common ideologies about applying personal names for streets. For instance, two plans of Ville de Hanoi, those of Leclanger (1890) and Charles Halais (1891), showed slight distinctions in applying names to the urban landscape.

According to Charles Halais's plan, the largest streets, including both those existing and those being built, should be reserved for senior French generals and officials, for instance, streets near by Hoàn Kiếm Lake would be commemorated with the names of President Léon Gambetta, General Brière de l'Isle, General Resident Paul Bert, etc. In contrast, the trend of commemoration in names on a "first come, first served" basis was shown in Leclanger's plan by applying names of junior soldiers who passed away in combats to large streets, so that one boulevard was named after Sergeant Bobillot and another was named after Lieutenant Carreau.

In the first two decades of the 20th century, the French administration

2 Translated as Bắc Kỳ xua in the Vietnamese version. 
expanded Hanoi city and built many new streets in both the indigenous area and the western area for the purpose of making Hanoi become little Paris. Firstly, new streets were numbered, then they were renamed, mostly, after people. War heroes and colonial officials still were preferred to other categories. Particularly, while the French administration honored some Vietnamese prominent cultural figures, very few French cultural figures were graced. Only Victor Hugo, a French writer, was dedicated.

In the process of building city, occasionally, some streets were given names of people who had relationships with streets. For examples, Rue SœurAntoine reminded people of the orphanage run by Madam Antoine; Rue Schneider reminded people of the publishing house run by Schneider. Some people representing for a civil society were commemorated, for instance, honoring medical people (Julien Blanc, Constant Mathis, and Calmette) or scholars (Leger, Gustave Dumoutier).

\subsection{Vietnamese honorees}

Very few Vietnamese figures were honored by the French colonial administration. Initial Vietnamese honorees, whose names were displayed on streets in the map of Leclanger in 1890, were two Kings of the Nguyễn Dynasty who were King Gia Long ${ }^{3}$, the founder of the Nguyễn Dynasty, and King Đồng Khánh ${ }^{4}$, the ninth Emperor of the Nguyễn Dynasty. These two kings were honored on the two largest streets near Hoàn Kiếm Lake.

The number of streets named after Vietnamese figures remained unchanged during the twenty-four following years. The following honorees were people who collaborated with the French colonial government, for instance, Nguyễn Trọng Hợp (Hiệp), a bureaucrat who represented Nguyễn Court in diplomatic activities with the French government, was commemorated in 1914; Đỗ Hữu Vị and Cao Đắc Minh, two Vietnamese pilots who served in the French air force, were commemorated in 1919 (Đào Thị Diến 2010, Vol. 1: 112-117). The number of Vietnamese people honored in names increased significantly between 1928 and 1931. Concretely, in 1928, among 36 streets were renamed, ten streets applied Vietnamese figures' names (Ville de Hanoi 03/1928: 172-173), also, nearly half of the renamed streets honored Vietnamese figures in 1931 (re-calculated from Đào Thị Diến 2010, Vol.1: 120-123). Particularly, half of the members of the Committee of Naming Streets nominated Vietnamese notables including Phạm Quỳnh, the

3 Gia Long was the imperial title of Nguyễn Ánh, the first emperor of the Nguyễn Dynasty (1802-1945).

4 Đồng Khánh was the imperial title of Nguyễn Phúc U’ng Đường, the ninth emperor of the Nguyễn Dynasty during French colonialism who was titled "vua bù nhìn" [the puppet emperor] (Quỳnh Cư \& Đỗ Đức Hùng 2009: 366-367). 
director of Nam Phong Magazine, and Nguyễn Khắc Nguyên, a municipal councilor (Ville de Hanoi 09/1930: 959).

Among 26 Vietnamese figures honored by the French government, eighteen elites were kings, war heroes, and bureaucrats and the remainder nominated prominent cultural figures. Some people who were symbols of patriotism and victories, such as Two Madame Trưng, General Lý Thường Kiệt, General Trần Hưng Đạo, and King Lê Lợi, were honored with streets. In fact, Vietnamese figures' names were applied to small streets in the suburban areas, evenly, for non-existed streets. Lý Thường Kiệt street and Đinh Tiên Hoàng street, for example, were two small streets near the railway station; Trần Hưng Đạo street was a lane to a small island in Trúc Bạch lake and Mạc Đĩnh Chi street was a lane in this island. However, the French colonial government honored King Gia Long, King Đồng Khánh, and Hoàng Cao Khải, the people considered as having relationships with French government, on boulevards belonging to areas for western people. Occasionally, there was a contrary idea that requested the French colonial government to change streets carrying Vietnamese people's names. For instance, the secretary of the Municipal Committee complained that Nguyễn $\mathrm{Du}$, a very well-known Vietnamese poet, was honored on the dirtiest street. Although it could be cleaned by people, that street would never be worthy to carry the poet's name 5 . Because of this complaint, Nguyễn Du was honored on a boulevard that was merged from three former streets.

\section{Rising patriotism and national identities under Trần Trọng Kim's Cabinet}

The Nation of Vietnam ${ }^{6}$, which led by the emperor Bảo Đại, the last king of the Nguyễn Dynasty, was founded after the Japanese army coup on March 9, 1945. More than one month later, on April 17, 1945, Bảo Đại proclaimed the birth of Trần Trọng Kim's Cabinet that then appointed Dr. Trần Văn Lai to the position of mayor of Hanoi city on July 19, 1945. Dr.

\footnotetext{
See in a post on Facebook of Dr. Đào Thị Diến, a researcher who has launched some research projects that focus on Hanoi urbanization during French colonialism. (https://www.facebook.com/daothidien/posts/1541789695928760) (latest access 2018-05-26).

6 Hardly official label used for calling this government. After the coup of Japanese Army, as King Bảo Đại mentioned, Vietnam became an "independent country" and Vietnamese people needed to "lập chính phủ để đối phó mọi việc" [form a government to deal with everything] (quoted by Trần Trọng Kim 1969: 49). King Bảo Đại called this government by Vietnamese terms "Nước Việt Nam" [Nation of Vietnam], "Việt Nam độc lập" [Independent Vietnam], "Nội các" [Cabinet], and "chính phủ Việt Nam" [Government of Vietnam]. However, to refer to this government, the term "Nội các Trần Trọng Kim" [Tran Trong Kim's cabinet] was more mentioned by historians (Phạm Hồng Tung 2009: 165-188; Marr 2013: 420, 488).
} 
Trần Văn Lai became the first Vietnamese figure to take the charge in this position after French colonialism. The existence of Trần Trọng Kim's Cabinet was erased by the uprising of the August Revolution on August 19, 1945 which was an important pathway for the birth of the Democratic Republic of Vietnam (DRV) which was declared by President Hồ Chí Minh on September 2, 1945.

Within a month of seizing power in Hanoi's Municipality, Mayor Trần Văn Lai orchestrated pulling down statues that had been built by the French government (Hung Việt Newspaper August 1945, No. 1) and (re)naming Hanoi's streets. These activities of Hanoi's Municipality became the act of "divest the landscape" and "reinforce the legitimacy of the newly independent state" (Yeoh 1992: 313) through removing the grid of street names which had been imposed by the French colonial council and renaming streets and places after Vietnamese war heroes who were spiritual symbols in the battles with invaders in history. Concretely, Hung Việt Newspaper (August 1945, No. 7-8) showed that among sixty of Hanoi's streets renamed by Mayor Trần Văn Lai and his colleagues forty-four streets were renamed after historical figures. This number included thirty-one honorees who were royal members, leaders of resistances, and war heroes, nine honorees who were prominent cultural figures, and four unknown people. Among forty-four honorees, three foreigners - a French doctor (Yersin), a Japanese king (Meiji 明治天皇), and a Chinese Revolutionary (Sun Yat-sen) - were commemorated in names by Mayor Trần Văn Lai and his colleagues.

The act of pulling down monuments and renaming streets by Trần Văn Lai's bureau was evaluated as the act of raise up the sacrifice for country from all social classes by creating monuments in large cities to commemorate achievements of heroes who sacrificed their lives for country ${ }^{7}$ (Trần Trọng Kim 1969: 59). Accordingly, Mayor Trần Văn Lai and his consultants tried to create new symbols on the Hanoi urban landscape by naming streets after people who had associations together. For instance, four streets around Rond Point Circulaire (now Ba Đình Square), which was the administrative center in French colonialism, were renamed after Vietnamese kings' names. Boulevard Pierre Pasquier in French colonialism was changed to Boulevard Hùng Vương ${ }^{8}$, mythical ancestors of Vietnamese people; boulevard Felix Faure was given the new name Two Madams Trung [Hai Bà Trung] $]^{9}$, the

7 “Chúng tôi lại muốn gây nuôi lòng hi sinh vì nước mà dựng tượng đài ở các nơi đô thị lớn để ghi những sự nghiệp của các bậc anh hùng chí sĩ đã quên mình vì nòi giống, vì tổ quốc" (Trần Trọng Kim 1969: 59).

8 Hùng Vuơng is a term to refer to mythical kings belonging to the Hồng Bàng era (2878$256 \mathrm{BC}$ ), the so-called forefathers of the Vietnamese people.

9 Trung Vuóng or Hai Bà Trung were two female kings who seized power after battles with Han invaders between 40 and $42 \mathrm{AD}$. 
sisters who were leaders of the battle with Han invaders in the first century; boulevard Brière de l'Isle was given a new name Quang Trung ${ }^{10}$; and boulevard Joffre was renamed Trùng Quang Emperor ${ }^{11}$. Also, giving new names for streets around Hoàn Kiếm Lake ${ }^{12}$ after the names of King Lý Thái Tổ ${ }^{13}$, King Lê Thái Tổ, and King Đinh Tiên Hoàng created the symbol of an independent country. Moreover, Vietnamese war heroes, for instance, General Trần Hưng Đạo (1226-1300) and General Lý Thường Kiệt (1019$1105)$, were commemorated together with the names of heroic kings to become a symbol of an independent nation and rising patriotism as Marr (2013) mentioned below:

During 1945-46, ideas about the nation which had excited the Vietnamese intelligentsia during the 1920s and 1930s spread among the public at large. Most important was patriotism, which meant loving one's land and people as a whole as opposed to traditional fidelity to king and parents. (Marr 2013: 6)

Particularly, to express the contestation with French colonialism, the committee of (re)naming Hanoi's streets commemorated in names some Vietnamese people who contributed to fights against the French army, for instance, Phan Đình Phùng ${ }^{14}$, Phạm Hồng Thái ${ }^{15}$, Phan Chu Trinh ${ }^{16}$, King Duy Tân ${ }^{17}$ who was still alive at the time of commemoration, and so on.

10 Quang Trung (1752-1792) was the imperial title of Nguyễn Huệ. He reigned during 1789-1792 and was the leader of the battle with Qing invaders in 1789.

11 Trùng Quang đế was the imperial title of Trần Quý Khoáng (?-1413), the second king of the Post-Trần [Hậu Trần] Dynasty (1409-1413) who was a leader of rebels contesting Ming invaders.

12 Lê Thái Tổ (1385-1433) was the imperial title of Lê Lợi, the first king of the Lê Dynasty (1428-1527) who reigned during 1428-1433. He was the leader of the resistance contesting Ming invaders. After the victory, King Lê Thái Tổ boated in a lake with his entourage. Suddenly, a tortoise appeared and asked King Lê Thái Tổ to give back the sword that had been sent to him by King of Maritime [Long Vương]. Because of this legend, the lake, then named Hoàn Kiếm (Hoàn means 'give back', and Kiếm means 'sword'), has been thought of as a spiritual area of not only Hanoi but also Vietnam.

13 Lý Thái Tổ was the imperial title of Lý Công Uẩn (974-1028) who was the founder of the Lý Dynasty (1010-1225). In 1010, Lý Thái Tổ moved the capital of the country from the ancient capital Hoa Lư to Thăng Long (now Hanoi).

14 Phan Đình Phùng (1847-1895), was a leader of Hương Khê Rebel (1885-1886), one of the rebels which supported the Cần Vương movement fighting French colonialism.

15 Phạm Hồng Thái (1884-1924) was a member of the Tâm Tâm xã, an organization of patriotic Vietnamese youths, who bombed the General President of Indochina Martial Merlin in Guangzhou in 1924.

16 Phan Chu Trinh (1872-1926) was a patriotic scholar who was exiled to Côn Đảo Island.

17 Duy Tân (1900-1945) was the imperial title of Nguyễn Phúc Vĩnh San, the eleventh emperor of the Nguyễn Dynasty. Because of protest from the French colony, King Duy Tân was arrested and exiled to Reunion Island. 
While Trần Văn Lai's bureau commemorated in a name King Duy Tân, surprisingly, this bureau seemed to ignore the existence of two streets that carried the names of Gia Long and Đồng Khánh, although King Gia Long was the first emperor, and King Đồng Khánh was the ninth emperor of the Nguyễn Dynasty. In contrast, the French municipality had commemorated in names these two kings on the two biggest streets in Hanoi city. I have not found any documents revealing information discussing (re)naming Hanoi streets among Trần Văn Lai's bureau. However, ignoring King Gia Long and King Đồng Khánh, and honoring Vietnamese war heroes allow me to think that Trần Văn Lai's bureau planned to promote patriotism through new street names.

Some of the people who were selected as prominent cultural figures were a historian (Lê Qúy Đôn), well-known notables (Trạng Trình, Hàn Thuyên), writers (Nguyễn Du, Nguyễn Đình Chiểu), scholars (Trương Vĩnh Ký, Nguyễn Trường Tộ), and a businessman (Bạch Thái Bưởi). Naming a street after Bạch Thái Bưởi ${ }^{18}$, a businessman, can be seen as an innovative act of Mayor Trần Văn Lai and his colleagues as businessmen, traditionally, were placed at the lowest position in the social order that included intellectuals (sĩ), farmers (nông), workers (công), and businessmen (thuơng).

\section{4. (Re)naming Hanoi streets during 1945-1954: A process of inheritance and elimination}

In the political conflicted context, to get the right of control over Vietnam and Indochina, political powers had to get the right of control over Hanoi because Hanoi became the target which political powers had to reach in the political contest after the World War II (Vũ Văn Quân et al. 2010: 195). In this process, (re)naming streets and memorials, "a tool to express their own postcolonial national identities" (Kang 2015: 33), was the urgent mission utilized by both Trần Trọng Kim's Cabinet and the DRV. No evidence showed that the DRV learnt the way of (re)naming streets from Trần Trọng Kim's Cabinet but the DRV asserted the act of (re)naming streets in cities had to be conducted "immediately" by municipal committees because the names imposed by French or Japanese governments were "vết tích nhục cho quốc thể" [imprints of stigma of nation] (Vietnam National Gazette September 1945: 13). Three months after the announcement of

18 Bạch Thái Buoơi (1874-1932) was a very famous Vietnamese businessman in the first half of the 20th century who focused his career on the trade of maritime transport, exploring coal, and printing. He presented his patriotism by naming his ships after titles of glorious dynasties and after Vietnamese heroic king's names such as Lạc Long, Hồng Bàng, Đinh Tiên Hoàng, and so on. See the link below for more details: https://vi.wikipedia.org/ wiki/Bạch_Thái_Bưởi (latest access 2018-02-03). 
(re)naming streets of the DRV, on the 1st December 1945, Hanoi's Municipality under the DRV launched a list of renamed Hanoi streets (Vietnam National Gazette May 1946: 287-288). This list showed that Hanoi's Municipal Committee expressed concretely the rules of (re)naming streets and memorials by which Hanoi's urban landscape was divided into several zones. Separately, the zone of "Khu Giải Phóng" [Liberation] was area to which would be applied the names of battlefields and rebels ( $Đ \hat{o}$ Luơng, Thái Nguyên, Tân Trào), the zone of "Khu Độc Lập" [Independence] would be given new names embedding symbols of an independent nation "Dân chủ Cộng hòa" [Democracy and Republic], "Nhân Quyền" [Human Rights], "Hùng Vương" [Kings Hung-forefather kings], an area near Red River would be given names embedding achievements of the Vietnamese people in maritime battles (Vạn Kiếp, Vân Đồn, Tây Kết, Bạch Đằng), and so on. Particularly, Hanoi's Municipal Committee offered an important rule of naming streets, that the largest streets should be served by the most wellknown historical figures (Vietnam National Gazette May 1946).

According to the list, the DRV renamed approximately 291 streets. Among these 291 street names, like the list of renamed streets launched by Trần Văn Lai's bureau, the number of streets which were given new names after people took the largest proportion, calculated at 148 streets. The following group was recorded as a group of handicraft and commodities names, estimated at fifty-seven streets. The third group belonged to a group of names transferred from local village names, place names, and ideologies (54 streets) which was followed by a group of names after geographical features (32 streets).

Like naming streets under French colonialism, duplicate names were applied: a name was given for a street and for a lane nearby that street. For examples, two streets were given names after pennames of Nguyễn Bỉnh Khiêm (Trang Trình Street and Bach Vân Lane); similarly, two streets were named after King Duy Tân (Duy Tân Street and Duy Tân Lane); furthermore, two streets were named after the scholar Ngô Sĩ Liên. Calculation from the list of renamed streets showed that except for four unknown people (Ngô Sĩ Vương, Nguyễn Văn Mai, Nguyễn Thị Bình, and Nguyễn Thành Hiên) the DRV honored approximately 113 historical figures who were royal members, war heroes, officials, and soldiers, and the remaining honorees were prominent cultural figures ${ }^{19}$. Although sharing more than thirty honorees launched by Trần Văn Lai's bureau, the DRV erased some categories named by the former bureau, such as a group of unknown people (Tam Tử Yến, Lê Thiện [or Lệ Thiên], Đội Đinh [Sergeant Dinh], Trần Huy Chữ [or Chử]), a Japanese King (Meiji), a spiritual figure (Lý Ông Trọng), and Emperor Trùng Quang. Besides honoring people belonging to ancient regimes, the DRV

19 See the Annexes for more details in Phùng Thị Thanh Lâm 2017. 
honored some new elements, for instance, mythical forebears of the nation (King Dương Vương, Lạc Long Quân), Chinese bureaucrats who reigned over the former Vietnam nation during the Northern Colony [Bắc thuộc] (Sĩ Nhiếp 士狺, Nhâm Diên 壬延, Tích Quang 錫光), and members of the Communist Party (Trần Phú, Tô Hiệu, Minh Khai, Nguyễn Văn Trạch).

French colonialism seized power again in 1946 and Hanoi became a battlefield where the force of resistance "hoạt động bí mật" [controlled secretly] and French force "hoạt động công khai" [controlled officially] (Vũ Văn Quân et al. 2010: 216). Between 1949 and 1951, Hanoi Municipality under French force proclaimed some decrees involving changed boundaries of "khu phố" [wards] that listed street names and functions of the ward's headers. Particularly, the Municipality under French force had launched a guidebook of street names that presented a comparative list of old names (existing during French colonialism) and new names which (re)named after political shifts and a brief introduction of name histories (Tòa Thị chính 1951). Also, the Municipality supported author Đinh Gia Thuyết to launch a book of Tiểu sứ của các tên phố [Stories of Hanoi street names] (Đinh Gia Thuyết 1951). Although these official documents were issued by a municipal government supported by France, the pride of being citizens of an independent country was expressed clearly both in the preface of the guidebook written by Mayor Thẩm Hoàng Tín and in the introduction by the author. As Đinh Gia Thuyết (1951: IV) mentioned in his book, the act of naming streets and public places after national heroes was a desire of the municipal committee that could encourage citizens "soi gương người trước" [to look at the mirror of forebears] "mà tranh đấu, hi sinh" [to fight and sacrifice] for an independent and free nation.

According to these documents, approximately 148 historical people were honored by the Hanoi Municipal bureau between 1946 and 1954. It seems that no more new symbols were applied by the Hanoi Municipality while this bureau excluded names belonging to groups of revolutionaries, communists, national forebears, and Chinese mandarins. This bureau inherited 113 personal names from the former political powers, Trần Văn Lai's bureau and the DRV. Although a bureau under the control of French force, only three streets were given French people's names (Henri de Mongezat, Yersin, and Madam Antoine). Nearly two-thirds of these people belonged to ancient regimes, the remainder, especially, honored people who participated in battles and movements to fight against French colonialism. Re-honoring King Gia Long and King Đồng Khánh, two names ignored by the Trần Văn Lai's bureau and by the DRV, and commemorating other members of the monarchy (Princess Huyền Trân, Lý Đạo Thành, Đoàn Nhữ Hài, and so on) can be considered as evidence determined by the preference for monarchy of the Hanoi Municipality. 


\section{5. (Re)naming streets after independence: Concerning commemoration between 1954 and 1975}

After the Great Victory in Điện Biên Phủ on the 7th May 1954, Hanoi became the metropolis of an independent nation. The government conducted various activities to build socialism in the North and to support the South in the resistance to invaders. In 1963, the President's Bureau [Phủ Thủ tuoóng] proclaimed the Directive [Chi thi] No. 23/TTg on 15 April 1963 to rename streets, communes, and hamlets (Chi cục Lưu trữ thành phố Hà Nội 1963). According to this document, there existed several unsuitable names which were based on names of colonial figures, invaders, and "phong kiến tay sai" [feudal lackeys]. This Directive requested people's committees to erase all names of colonial figures, names of kings and mandarins who had not much contribution to the country, names of Vietnamese spies and betrayers, and names of people belonging to exploitative classes. Following this Directive, the Hanoi Department of Culture provided a list of people recommended for re-commemoration which was divided into five groups. Two of these groups related to erroneous street names (for example, Ta Hiền Street needed to replace by Ta Hiện Street) and to people honored on streets that were unequal to their contribution (for instance, a very small street was used to honor Nguyễn Trãi, a very important figure of the country). The three remaining groups focused on people whose contribution to the country had to be reevaluated. The first group included personal street names related to "tàn tích phong kiến" [feudal imprints], such as, Phan Thanh Giản, Trương Vĩnh Kí, Bạch Thái Bưởi; the second group included names of people who had "sự nghiệp không đáng kể" [a trivial career], for instance, Lê Phụng Hiểu, Princess Huyền Trân, Lê Như Hổ, Cao Bá Nhạ, Tôn Thất Thiệp, and so on; and the third one included people who were still alive such as Nguyễn Thị Chiên $^{20}$, a militia leader during resistance to French invaders, and La Văn Cầu ${ }^{21}$, who lost an arm in a battle with French invaders. They were commemorated in names on streets beyond the dike of the Red River between 1954 and 1965 (Trung tâm Lưu trữ thành ủy Hà Nội 1955).

Results of the examination of eliminated people showed that, although the war had ended, patriotism was still considered to be the most important characteristic of Vietnamese people. The evaluation made by Hanoi People's Committee accounted for the changes of street names that were still based on this traditional value. For instance, Phan Thanh Giản had committed a crime which led to the selling of the country [bán nuoóc] during early French colonial

20 Wikipedia, Nguyễn Thị Chiên (2018, https://vi.wikipedia.org/wiki/Nguyễn_Thị_Chiên).

21 Ban Thi đua Khen thưởng Trung ương (2011, http://banthiduakhenthuongtw.gov.vn/ tabid/74/Entry/487/Default.aspx) and Wikipedia, La Văn Cầu (2018, https://vi.wikipedia. org/wiki/La_Văn_Cầu). 
time; Trương Vĩnh Kí was a genius but "cái học của Trương Vĩnh Kí thực chất là phục vụ cho đế quốc nhiều hơn cho đất nước" [his knowledge, in fact, used to serve the empire much more than the country] (Sở Văn hóa Hà Nội 1963); Cao Bá Nhạ's literature expressed his weak ideologies. Although honoring patriotism, Hanoi People's Committee did not mention the re-commemoration of King Duy Tân and King Hàm Nghi, the two kings who were leaders of resistant movements, contrarily, they were honored by Trần Văn Lai's bureau and other political authorities during 1945-1954. After changes, street names for these two kings did not appear in the list of street names or in the maps of Hanoi city. The movement of eliminating feudal imprints, probably, swept honoring the two kings far from the urban landscape.

\section{Conclusion}

Naming Hanoi streets after personal names, a political-social trend which emerged since French colonial times, has developed into a process of "forgetting or remembering" (Alderman 2014: 202). In other words, Azaryahu (2009: 53-54) has pointed out that "street names intersect between urban space and official ideologies and mediate between political elites and 'ordinary' people".

In the colonial time, the French administration imposed new street names originating in western countries on the urban landscape of ancient Hanoi city which could be considered as imprints of winners on a new land. However, from the motivations of (re)naming Hanoi streets after Vietnamese political powers in postcolonialism, the process of remembering honored traditional values which concentrate on increasing patriotism. Therefore, it erased all things that conflicted with this value and became the reason for the act of elimination of all street names commemorating foreigners and several street names after Vietnamese people which were imposed by the French colonial administration. Furthermore, the elimination included innovative elements, for instance, Meiji and Sun Yat-sen; probably, they belonged to countries which invaded Vietnam.

In the context of the political conflict, Vietnamese political powers did not differ in choosing people who were symbols of conflicts with invaders. It seems that people will not concern greatly honoring heroes because they put the images of heroes in the shadow of patriotism. According to Đinh Gia Khánh (1960: 26-27), the power accumulated by forebears concentrated on symbols of national heroes which were considered the traditional flames. Also, Đinh Gia Khánh highlighted that many historical heroes had borrowed prestige from former heroes to attract the trust of contemporary people to them ${ }^{22}$.

22 “Trong tâm lý nhân dân ngày xưa, sức mạnh mà ông cha đã tích lũy đều tập trung vào nhân vật anh hùng dân tộc. Và những hình tượng về anh hùng dân tộc chính là những 
However, with people who had made an indirect contribution to the resistance of the nation, various evaluations were imposed. To illustrate, I would like to give an example of naming a street after Princess Huyền Trân during 1946-1954. The Princess was a daughter of Emperor Trần Nhân Tông. In 1306, she was sent to the Champa Empire to be a queen in a political marriage (Quỳnh Cư \& Đỗ Đức Hùng 2009: 126-128). The Vietnamese municipal administration under French rule during 1946-1954 commemorated the princess because after her marriage two areas named Châu Ô and Châu Lý were dedicated to the Empire Viet. After 1954, the Hanoi municipal committee asserted this marriage was "chỉ là một âm mưu chính trị" [ a political plot only] and renamed the street after female General Bùi Thị Xuân (Department 1963).

Analyzing the process of (re)naming Hanoi streets in postcolonial time shows that it is difficult to estimate people's contribution. In 1963, the Institute of History provided a classification of honored people (Department 1963). According to this document, there were some labels applied for people who would be honored on streets, for instance, "anh hùng dân tộc" [national heroes], "danh nhân văn hóa" [cultural figures], "lãnh tụ cách mạng và danh nhân văn hóa thế giới" [leaders of revolutions and international cultural figures]. Although the Institute of History attached lists of people to each label, it still had not any directions about the criterion of classification. So far, this is still an unanswered question.

\section{Acknowledgements}

I would like to thank two referees for their supportive comments on the preliminary version of my paper. Specially, I would like to acknowledge Paul Woodman for being the English editor of this article. I would also like to thank Dr. Đào Thị Diến and Dr. Sandra Kurfürst for their revision of the abstracts of this paper in French and German, respectively. Finally, I am very grateful Nguyễn Đức Minh for his cartographic work that illustrated my ideas for this research.

ngọn đuốc truyền thống ấy. [...]. Trong thực tế phải tính đến nhiều anh hùng lịch sử thường hay mượn uy thế của anh hùng đời trước để tranh thủ sự tín nhiệm của nhân dân đương thời đối với bản thân mình" (Đinh Gia Khánh 1960: 26-27). 


\section{References}

Alderman, Derek H. 2014. Naming streets, doing justice? Politics of remembering, forgetting, and finding surrogates for African American slave heritage. In Proceedings of the International Symposium on Toponymy, Seoul, 7-9 November 2014, 193-228. Korea: Kyung Hee University Press.

Azaryahu, Maoz. 2009. Naming the past: The significance of commemorative street names. In Berg, Laurence D. \& Vuolteenaho, Jani (eds.), Critical toponymies: The contested politics of place, 53-70. Burlington: Ashgate.

Ban Thi đua Khen thưởng Trung ương [Committee of National Emulation and Compliment]. 2011. Tự thuật thành tích của chiến sĩ La Văn Cầu [Self-narration on achievements of soldier La Văn Cầu]. (http://banthiduakhenthuongtw.gov.vn/tabid/74/Entry/487/Default.aspx) (Accessed 2018-02-03.)

Bourrin, Claude. 2007. Bắc Kỳ xua [Ancient Tonkin]. Hanoi, Vietnam: Transport Publishing House.

Chi cục Lưu trữ thành phố Hà Nội [Department of Hanoi Municipal Archives]. 1963. Thông tư, chỉ thị và công văn của Phủ Thủ tướng, Bộ Nội vụ, Bộ Văn hóa, Sở Văn hóa, Ban Dân chính Hà Nội về việc điều chỉnh địa giới và đổi tên phố, xã thôn ở Hà Nội [Edicts, Directives, and Documents of the President's Bureau, Ministry of Home Affairs, Ministry of Culture, Department of Culture [Hanoi], about changes of limitation and renaming streets, communes, and hamlets in Hanoi]. In Phông Ủy ban Nhân dân thành phố Hà Nội [Record of Hanoi People's Committee], Code: 3775.

Đào Thị Diến. 2010. Hà Nội qua tài liệu và tu liệu luu trũ 1873-1954 [Hanoi through archival documents 1873-1954], vol. 1. Hanoi, Vietnam: Hanoi Publisher.

Đinh Gia Khánh. 1960. Lời giới thiệu sách Việt điện u linh [Introduction to the tales of Vietnamese spirits], 5-31. Gia Lai: Vietnam, Hong Bang Publisher.

Đinh Gia Thuyết. 1951. Tiểu sủ các tên phố Hà Nội [Stories of Hanoi street names]. [N.p.].

Ganter, D. 1895. Recueil de la Législation en vigueur en Annam et au Tonkin Depuis l'origine du Protectorat jusqu'au $1^{\text {er mai }}$ 1895. Hanoi: F.H Schneider, Imprimeur Éditeur.

Gill, Graeme. 2005. Changing symbols: The renovation of Moscow place names. The Russian Review 64, July 2005, 480-503.

Gouvernement Général de l'Indo-chine. 1905. Ville de Hanoi (Tonkin), Historique, Développement financier, Règlementation administrative et 
Fonctionnement des divers services municipaux de la Ville de Hanoi. Hanoi.

Halais, Charles. 1891. Plan de Hanoi et de ses environs (http://gallica.bnf.fr/ark:/12148/btv1b8439869f/f1.item.r=Plan\%20de\% 20Hanoi\%20et\%20ses\%20environs.zoom) (Latest access 2018-05-25.)

Hebbert, Michael. 2005. The street as locus of collective memories. Environment and Planning D: Society and Space 23, 581-596.

Hung Việt Newspaper. August 1945. Code: J.524, Vietnam National Library.

Kang, Peter. 2015. Remapping national geography in the street-naming of Ho Chi Minh city. Journal of Geographical Science 77, 31-48.

Lacroix-Sommé, L. \& Dicken, R.J. \& Burtschy, A.J. 1933. Indochine Addreses $1^{\text {ere }}$ année 1933-1934: Annuaire Complet (Européen et Indigène) de toute de l'Indochine, Commerce, Industrie, Plantations, Mines, Addreses particulieres. Saigon: Imprimerie Albert Portail.

Lê Chất. 1818-1821. Bắc thành địa dư chí lục [Monograph on geography of the North Citadel]. In Địa chí Thăng Long Hà Nội trong thu tịch Hán Nôm [Geography of Thang Long Ha Noi in Han-Nom script works], 475-508. Hanoi, Vietnam: International Publisher.

Leclanger, M.V. 1890. Plan de la ville de Hanoi à échelle de 1/10000 (http://gallica.bnf.fr/ark:/12148/btv1b530277467.r=Plan\%20de\%20la\% 20ville\%20de\%20Hanoi?rk=107296;4) (Latest access 2018-05-25.)

Linfu, Hua. 2014. China's toponymic influence upon Korean Peninsula during history period. In Proceedings of the International Symposium on Toponymy, Seoul, 7-9 November 2014, 76-116. Korea: Kyung Hee University Press.

Lý Tế Xuyên. 1960 [reprinted 2012]. Việt diện u linh [The tales of Vietnamese spirits]. Gia Lai, Vietnam: Hồng Bàng Publisher.

Marr, David. 2013. VIET NAM State, War, And Revolution (1945-1946). London, England: University of California Press.

Ngô Đức Thọ. 1997. Chũ húy Việt Nam qua các triều đại (Les caractères interdits au Vietnam à travers l'Histoire). Hanoi, Vietnam: Culture Publisher.

Palonen, Emillia. 2008. The city-text in post-communist Budapest: Street names, memorials, and the politics of commemoration. GeoJournal 73, 219-230.

Papeterie Imprimerie Militaire Administrative. 1951. Hanoi en 9 Coupures.

Phạm Hồng Tung. 2009. Nội các Trần Trọng Kim, bản chất, vai trò và vị trí lịch sủ [Tran Trong Kim's Cabinet - Nature, historic role and position]. Hanoi, Vietnam: National Political Publishing House.

Phùng Thị Thanh Lâm. 2017. Địa danh đuoơng phố Hà Nộ tù̀ 1888 đến 2008 (qua tu liệu bốn quận Hoàn Kiếm, Ba Đình, Đống Đa, Hai Bà Trung) [Hanoi street names during the period 1888-2008 (based on data of 
four districts Hoan Kiem, Ba Dinh, Dong Da, Hai Ba Trung]. Doctoral dissertation on Vietnamese Studies, VNU-Institute of Vietnamese Studies and Development Science. (In Vietnamese.)

Quỳnh Cư \& Đỗ Đức Hùng. 2009. Các triều đại Việt Nam [Vietnamese Dynasties]. Hanoi, Vietnam: Culture - Information Publisher.

Sở Văn hóa Hà Nội [Hanoi Department of Culture]. 1963. Danh sách các đường phố và các ngõ Hà Nội đề nghị đổi tên [Proposal for renaming streets and lanes in Hanoi].

Tent, Jan \& Blair, David. 2011. Motivations for naming: The Development of a toponymic typology for Australian Placenames. Names 59(2), 67-89.

Tòa Thị Chính thành phố Hà Nội [Hanoi Municipality]. 1951. Bảng chi dẫn các phố Hà Nội [A guide of Hanoi streets].

Trần Trọng Kim. 1969. Một cơn gió bụi [A whirling wind and dust]. Saigon: Vĩnh Sơn Publisher.

Trung tâm Lưu trữ thành ủy Hà Nội [Center of Hanoi Archival Communist Party]. 1955. Danh sách các khu phố, đường phố thuộc nội ngoại thành Hà Nội năm 1955 [List of sectors and streets in Hanoi city and suburban areas in 1955]. In Phông Ủy ban Hành chính thành phố Hà Nộ [Record of the Administrative Committee of Hanoi], Code: 692.

Vietnam National Gazette. September 1945, No. 1. (http://baochi.nlv.gov.vn/ baochi/cgi-bin/baochi?a=d\&d=JwvzO19450929\&e=-------vi-20--1-img-txIN------) (Latest access 2018-05-26.)

Vietnam National Gazette. May 1946, No. 21. (http://baochi.nlv.gov.vn/ baochi/cgi-bin/baochi?a=d\&d=JwvzO19460525\&e=-------vi-20--1-img-txIN------) (Latest access 2018-05-26.)

Ville de Hanoi: Bulletin Municipal. 03/1928. Attribution des Noms des Rues, 171-172.

Ville de Hanoi: Bulletin Municipal. 09/1930. Arrêté nommant une Commission en vue de choisir des noms des Francais et Annamites pour les affecter à des voies de la ville qui portent encore des numéros, 959.

Vũ Văn Quân \& Đoàn Minh Huấn \& Nguyễn Quang Ngọc. 2010. Quản lý và phát triển Thăng Long - Hà Nội Lịch sứ và bài học [Management and Development Thang Long - Ha Noi History and Lessons]. Hanoi, Vietnam: Hanoi Publisher.

Wikipedia. 2018. La Văn Cầu. (https://vi.wikipedia.org/wiki/La_Văn_Cầu) (Accessed 2018-02-03.)

Wikipedia. 2018. Nguyễn Thị Chiên. (https://vi.wikipedia.org/wiki/Nguyễn Thị_Chiên) (Accessed 2018-02-03.)

Yeoh, Brenda S.A. 1992. Street names in colonial Singapore. Geographical Review 82(3), 313-322. 